\title{
Analysis of the suitability of Polish soil texture classification for estimating soil water retention and hydraulic properties
}

\begin{abstract}
The objective of this study was to examine whether the Polish soil textural classification is useful for evaluation of soil water retention and hydraulic properties and, furthermore, for determining which textural classes are characterized by the highest diversity of soil water retention and hydraulic properties. The texture triangle was divided into a $1 \%$ grid of particle-size classes resulting in 5151 different data points. For each data point, soil water retention parameters and saturated hydraulic conductivity were obtained using the ROSETTA program. The silt classes showed the highest uncertainty in the estimation of the saturated water content based on the soil texture. These classes are characterized by high variations of saturated water content within the class. Estimations of field capacity and permanent wilting point on the basis of textural classes are encumbered with highest errors for $g p$, $p g, p l$ and $p y g$ soils, which are characterized by the highest values of coefficient of variation. Saturated soil hydraulic conductivity is better classified into homogeneous classes by the Polish texture classes than by the clusters obtained by the $k$-means cluster analysis based on the soil hydraulic and retention properties. Soil water retention parameters are better classified into homogeneous groups by the $k$-means cluster analysis than by the traditional textural classes. Cluster analysis using the $k$-means can be helpful for grouping similar soils from the point of view of their retention properties.
\end{abstract}

Keywords: soil textural classes, soil hydraulic properties, cluster analysis

\section{INTRODUCTION}

Understanding the soil-water-atmosphere-plant processes, in particular on regional scales, requires grouping soils on the basis of their hydraulic properties. Classical methods of direct measurement of soil hydraulic properties are known to be costly, time consuming and impractical for regional scale application (Dane and Topp 2002, Ramos et al. 2013). Hence, pedotransfer functions (PTFs) have been developed as an alternative to traditional methods to indirectly estimate soil water retention properties and hydraulic parameters from basic soil physical and chemical properties (Bouma 1989, Vereecken et al.1989, McBratney et al. 2002, Pachepsky and Rawls 2004) especially on regional scales. The use of PTFs in soil-water modelling is well accepted if no detailed data are available. The majority of the available PTFs are based on the assumption that soil texture is the dominant variable in determining the soil water retention and hydraulic properties whereas the other soil variables, such as bulk density or organic matter content, only have secondary effects (Twarakavi et al. 2010). The simplest PTFs have been developed to provide estimates of average soil water retention properties or hydraulic parameters for different textural classes (Wösten et al. 1995, Schaap and Leij 1998, Al Majou et al. 2008, Bruand et al. 2003, Ramos et al. 2013). Soil texture refers to the proportions of various particle-size classes in a given soil volume and is described in terms of soil textural class usually presented in a ternary diagram.

Saxton et al. (1986) have divided the soil texture triangle into grids of $10 \%$ sand and $10 \%$ clay content increments to develop the texture based PTFs for generalized predictions of soil hydraulic properties in each grid cell. Twarakavi et al. (2010) have also focused on the relations between the texture triangle and soil hydraulic properties using the ROSETTA PTFs (Schaap et al. 2001) taking into account various soil texture possibilities (i.e., combinations of sand, silt, and clay percentages). Bormann (2007, 2008, 2010) has shown that some soil textural classes from the German soil texture (Ad-Hoc-AG Boden 2005) classification show a large variation in simulated soil water balances, and that this variability significantly differs between different soil texture classes. Similar results have been obtained by Groenendyk et al. (2015) using the USDA (Soil Survey Division Staff 1993) soil texture classification, hence texture classification has not been primarily designed for hydrological mapping purposes (Groenendyk et al. 2015). 
The objective of this study was to examine whether the Polish soil textural classification PTG 2008 (Polskie Towarzystwo Gleboznawcze 2009) is useful for prediction of soil water retention and hydraulic properties and, further, for determining which textural classes are characterized by the highest diversity of the soil hydraulic parameters. PTFs were used as it is difficult to represent the entire soil texture triangle by soil hydraulic properties obtained from direct field and laboratory measurements.

\section{MATERIALS AND METHODS}

According to the Polish soil texture classification PTG 2008 (Polskie Towarzystwo Gleboznawcze 2009) the soil texture triangle is divided into 16 texture classes: six loam classes, four clay classes, three silt classes and three sand classes. In our study, we used the following procedure for soil classification from the hydraulic and water retention standpoint. Firstly, the four soil hydraulic parameters $\theta_{r}, \theta_{s}, \alpha, n$ from the van Genuchten (1980) equation and saturated hydraulic conductivity $\left(K_{s}\right)$ were estimated throughout the entire soil texture triangle using the ROSETTA program (Schaap et al. 2001) so that the various soil texture possibilities were considered:

$$
\theta(h)=\left\{\begin{array}{c}
\theta_{r}+\frac{\theta_{s}-\theta_{r}}{\left[1+(a h)^{n}\right]^{m}} h<0 \\
\theta_{s} \quad h \geq 0
\end{array}\right.
$$

where $\theta(h)$ is the volumetric water content $\left(\mathrm{cm}^{3} \cdot \mathrm{cm}^{-3}\right)$ as a function of the pressure head $h(\mathrm{~cm}), \theta_{s}$ and $\theta_{r}$ are the saturated and residual volumetric water contents $\left(\mathrm{cm}^{3} \cdot \mathrm{cm}^{-3}\right)$, respectively, $\alpha\left(\mathrm{cm}^{-1}\right), n$ and $m$ (dimensionless) are the van Genuchten shape parameters where $m=1-1 / n$. The ROSETTA PTFs (pedotransfer functions) use artificial neural networks and can predict the soil hydraulic parameters needed as a function of the soil texture and bulk density (H3 model). By changing each soil particle size fraction by $1 \%$ intervals, 5151 unique data points (soils) were identified in the textural triangle. Percentages of sand, silt, clay and bulk density were used as an input to ROSETTA, so that the results of soil water retention parameters and saturated hydraulic conductivity shown in a ternary diagram are only a function of soil fraction proportion and bulk density. Bulk density $(\rho b)$ is an important soil physical property needed for estimating soil water characteristic (Boucneau et al., 1998). Differences in bulk density values among soils are primarily attributed to differences in particle size distribution and organic carbon contents (Manrique and Jones 1991, Hollis et al. 2012, Abdelbaki 2016). For this reason, the pedotransfer function (PTFs) proposed by Leonaviciute (2000) was used to estimate the bulk density values in 5151 soil data points, assuming $1.2 \%$ of organic carbon content as a mean for Polish topsoils (Terelak et al. 2001). According to Schaap et al. (2001) for H3 model, the root mean square error (RSME) values of estimated $K_{s}$ and water retention data (on the basis of van Genuchten (1980) equation) were $0.666 \mathrm{log} \mathrm{cm} \cdot \mathrm{d}^{-1}$ and $0.068 \mathrm{~cm}^{3} \cdot \mathrm{cm}^{-3}$ respectively.

Using the soil hydraulic parameters from the van Genuchten (1980) equation, the field capacity $\left(\theta_{f c}\right)$ and the permanent wilting point $\left(\theta_{w p}\right)$ were calculated at the water potentials of $-10 \mathrm{kPa}$ and $-1500 \mathrm{kPa}$ respectively. On the basis of $\theta_{s}, \theta_{f c}$ and $\theta_{w p}$ the drainable porosity $\left(D P=\theta_{s}-\theta_{f c}\right)$ and the available water capacity $\left(A W C=\theta_{f c}-\theta_{w p}\right)$ were calculated. Then the 5151 data points representing various combinations of particle-size classes and the bulk density were grouped according to PTG 2008 (Polskie Towarzystwo Gleboznawcze 2009). For individual soil textural classes, the basic statistics of soil water retention parameters and saturated hydraulic conductivity were calculated. The next step was to use the $k$-means clustering method for classifying (into 16 clusters) the data of soil hydraulic and water retention parameters $\left(K_{s}, \theta_{s}, \theta_{f c^{\prime}}\right.$ $\left.\theta_{w p}, A W C, D P\right)$. Prior to the application of the $k$-means clustering algorithm, the data were standardized so that each of the soil hydraulic properties had the same impact on the clustering process.

\section{RESULTS AND DISCUSSION}

The distributions of the soil water retention parameters and saturated hydraulic conductivity are presented in the ternary diagrams in Figure 1. Table 1 shows the basic statistics of soil water retention parameters and saturated hydraulic conductivity for 16 soil textural classes. The highest mean values of $K_{s}$ were obtained for the soils with $p l, p s, p g$ and $p y z$ (symbols are explained in the caption of Figure 1) texture but the highest values of the coefficient of variation (CV) were obtained for $g z, g p i$, pyi and $p y g$ soil textures (from 36 to $50 \%$ ). Similar results have been obtained by Groenendyk et al. (2015) using the USDA soil textural triangle. As far as $\theta_{s}$, is concerned, the soil textural classes pyz, ipy and gpyi showed the highest mean values $\left(0.453,0.436\right.$ and $0.435 \mathrm{~cm}^{3} \cdot \mathrm{cm}^{-3}$, respectively), while the $p l, g p$ and $p s$ textural classes showed the lowest $\left(0.366,0.367\right.$ and $0.370 \mathrm{~cm}^{3} \cdot \mathrm{cm}^{-3}$, respectively). The values of the $\mathrm{CV}$ for $\theta_{s}$ were the highest for pyi, pyg and pyz (from 4,5 to 6,3\%), while the lowest were found in the $p s$ and $p l$ soils ( 0.4 and $0.5 \%$, respectively). With increasing content of clay and silt fractions, the values of $\theta_{s}$ significantly increased 


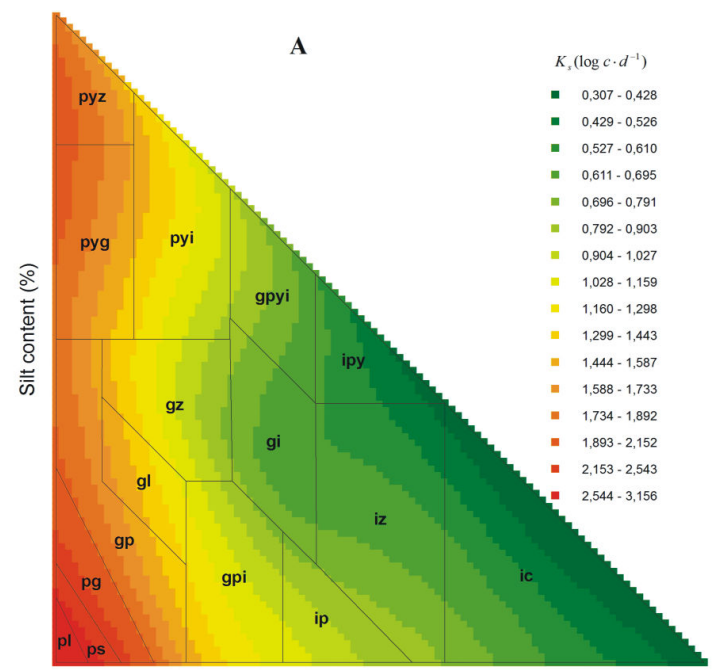

Clay content $(\%)$

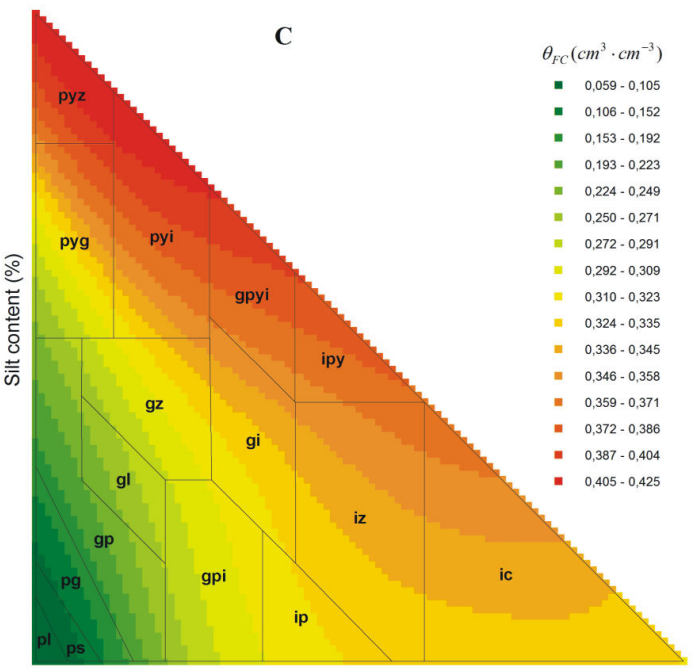

Clay content $(\%)$

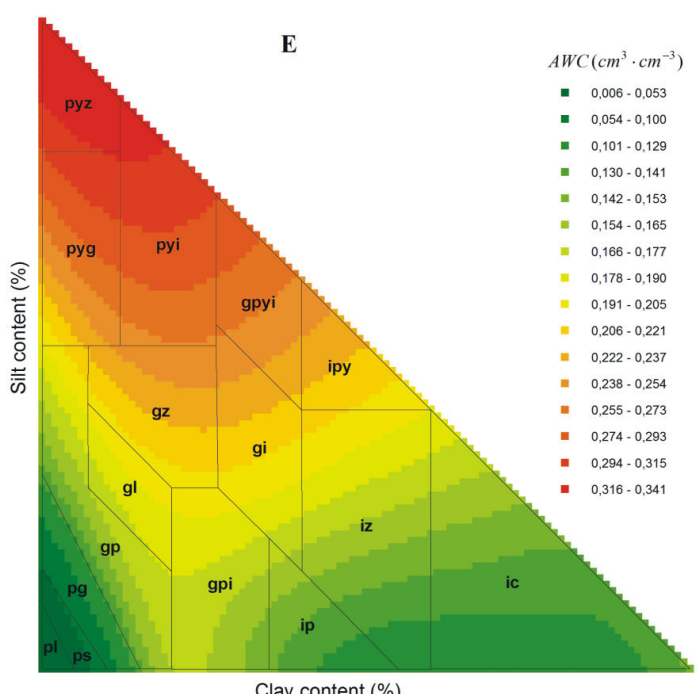

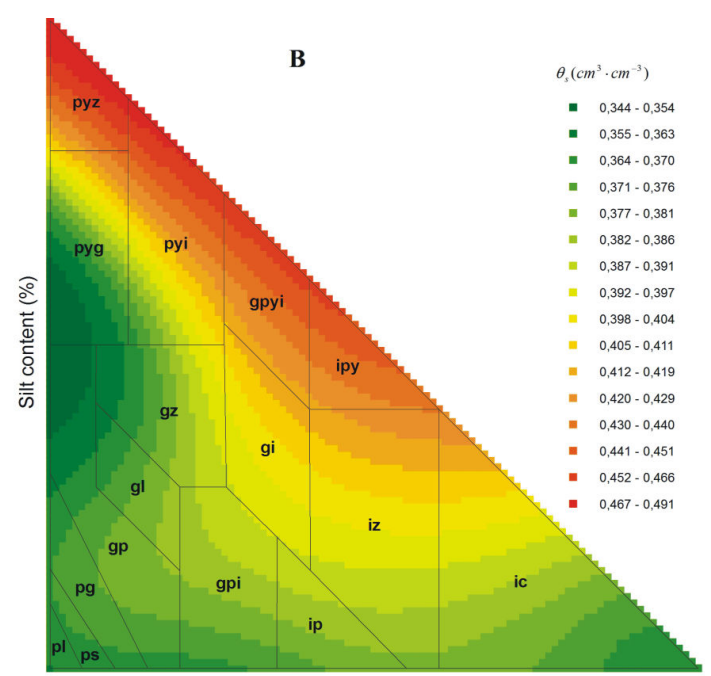

Clay content $(\%)$

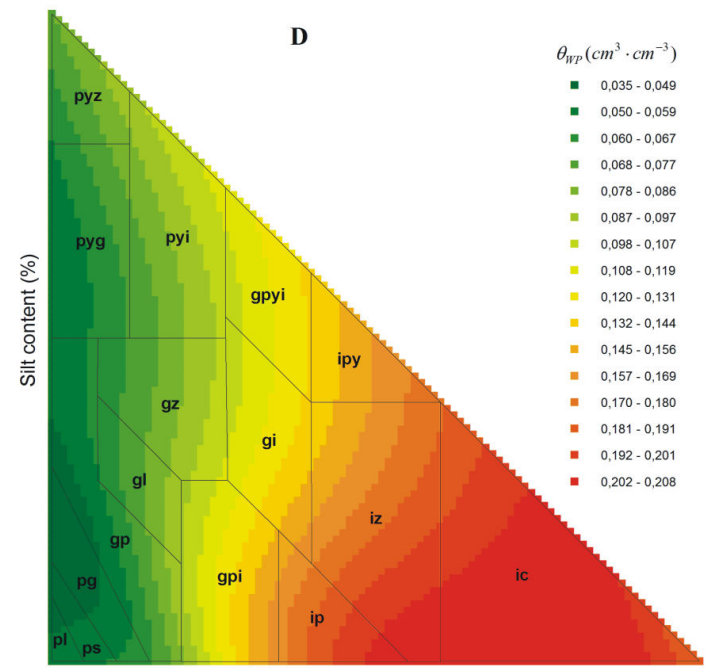

Clay content (\%)

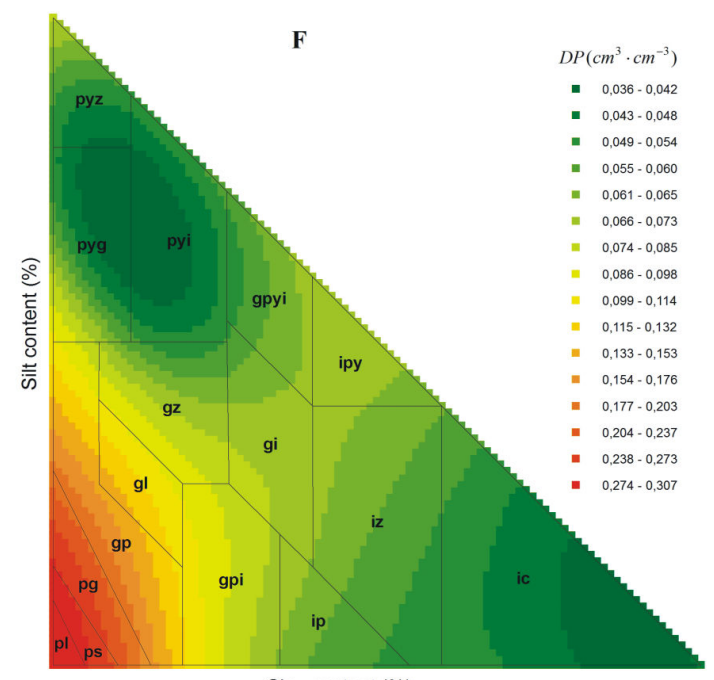

Clay content (\%)

FIGURE 1. Spatial patterns of the saturated hydraulic conductivity $\left(K_{s}\right)$ and the soil water retention parameters $\left(\theta_{s}, \theta_{f c}, \theta_{w p}, A W C\right.$ and $D P$ ) on the Polish soil texture PTG 2008 triangle: pl - sand, ps - weakly loamy sand, pg - loamy sand, gp - sandy loam, gl -light loam, gpi - sandy clay loam, gz - loam, gi - clay loam, gpyi - silty clay loam, pyg - silt loam, pyi - heavy silt, pyz - silt, ip - sandy clay, ipy - clayey silt, iz - clay, ic - heavy clay 


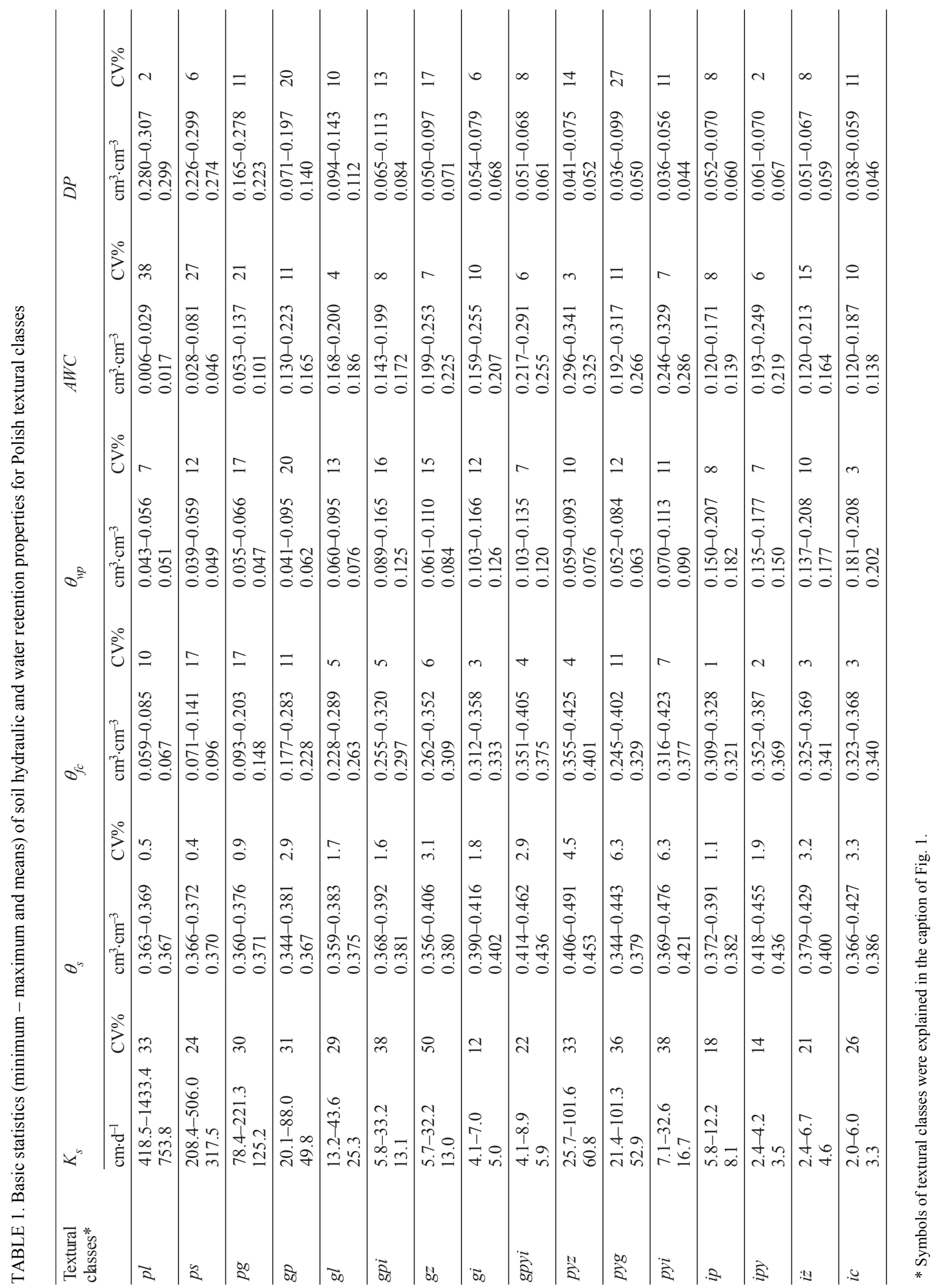


(Fig. 1b). Soil water contents at $-10 \mathrm{kPa}$ matric potential $\left(\theta_{f}\right)$ were lower in the coarser textural classes and increased diagonally with the increment of clay and silt contents (Fig. 1c), therefore the highest mean values of $\theta_{f c}$ were in the $p y z$, pyi and gpyi soils $(0.401$, 0.377 and $0.375 \mathrm{~cm}^{3} \cdot \mathrm{cm}^{-3}$ respectively). For the textural classes $p l, p s, p g, g p$ and $p y g$ the highest values of the $\mathrm{CV}$ (from $10 \%$ to $17 \%$ ) were observed. This means that the extrapolation of $\theta_{f c}$ data to another soil within the same textural class will be burdened with high error. These soils, especially $p y g$ and $p g$, exhibited also the highest values range of $\theta_{f c}$. For the soil pyg it was $0.157 \mathrm{~cm}^{3} \cdot \mathrm{cm}^{-3}$ while for the $p g$ textural class $0.110 \mathrm{~cm}^{3} \cdot \mathrm{cm}^{-3}$. The values of $\theta_{w p}$ were determined mainly by the clay fraction content (vertical limit) (Fig. 1d). The lowest values of $\theta_{w p}$ were in the coarser textural classes (from 0.046 to $0.050 \mathrm{~cm}^{3} \cdot \mathrm{cm}^{-3}$ ), while the highest in the ipy, iz, ip and ic (from 0.150 to $0.202 \mathrm{~cm}^{3} \cdot \mathrm{cm}^{-3}$ ) soils. Highest values of the $\mathrm{CV}$ of $\theta_{w p}$ were obtained for $g p, p g$, gpi and $g z$ soil. From the point of view of plant production, the soil properties related to $A W C$ are important. The coarser textural classes and the soils with higher clay content had lower $A W C$ then the other classes (Fig. 1e). According to Al Majou et al. (2008), the soils with high clay texture showed a high proportion of water that is not available for plants. The highest mean values of $A W C$ have the soils from the textural classes $p y z$, pyi, pyg and gpyi. These textural classes store from 0.325 $\mathrm{cm}^{3} \cdot \mathrm{cm}^{-3}$ to $0.256 \mathrm{~cm}^{3} \cdot \mathrm{cm}^{-3}$ of the water available for growing crops. The highest ranges of $A W C$ were established for the textural classes $g p, i z$, gi and $p y g$ (from $0.093 \mathrm{~cm}^{3} \cdot \mathrm{cm}^{-3}$ for $g p$ to $0.125 \mathrm{~cm}^{3} \cdot \mathrm{cm}^{-3}$ for $p y g)$. The highest values of the $\mathrm{CV}$ were obtained for $p l, p s$ and $p g$ soil texture, which means that estimation of the $A W C$ on the basis of these textural classes and soil bulk density is burdened with high uncertainty. Along with $A W C$, one of the most important properties of soil water retention is the drainable porosity $(D P)$. The $D P$ is the pore volume of water that is removed when the water table is lowered in response to gravity and in the absence of evaporation. The highest mean values of $D P$ were obtained for the soils $p l, p s$ and $p g$ (from $0.299 \mathrm{~cm}^{3} \cdot \mathrm{cm}^{-3}$ for $p l$ to $0.223 \mathrm{~cm}^{3} \cdot \mathrm{cm}^{-3}$ for $p g$ ) texture, while the lowest for the soils of the textural classes pyi, ic and $p y g$ (from $0.044 \mathrm{~cm}^{3} \cdot \mathrm{cm}^{-3}$ for pyi to $0.050 \mathrm{~cm}^{3} \cdot \mathrm{cm}^{-3}$ for pyg) (Fig. 1f, Table 1). The highest range of $D P$ was found for $p s, p g$ and $g p$ (from $0.072 \mathrm{~cm}^{3} \cdot \mathrm{cm}^{-3}$ to $0.126 \mathrm{~cm}^{3} \cdot \mathrm{cm}^{-3}$ ), while the lowest range of $D P$ was obtained for the soil ipy, ip and gpyi (from $0.008 \mathrm{~cm}^{3} \cdot \mathrm{cm}^{-3}$ to $0.017 \mathrm{~cm}^{3} \cdot \mathrm{cm}^{-3}$ ). For $p y g, g p, g z$ and $p y z$, the highest $\mathrm{CV}$ values (from
FIGURE 2. Resulting clusters, applying the $k$-means cluster analysis based on $K_{s} \theta_{s}, \theta_{f c}$, $\theta_{w p} A W C$ and $D P$ on the background of Polish soil texture PTG 2008 triangle

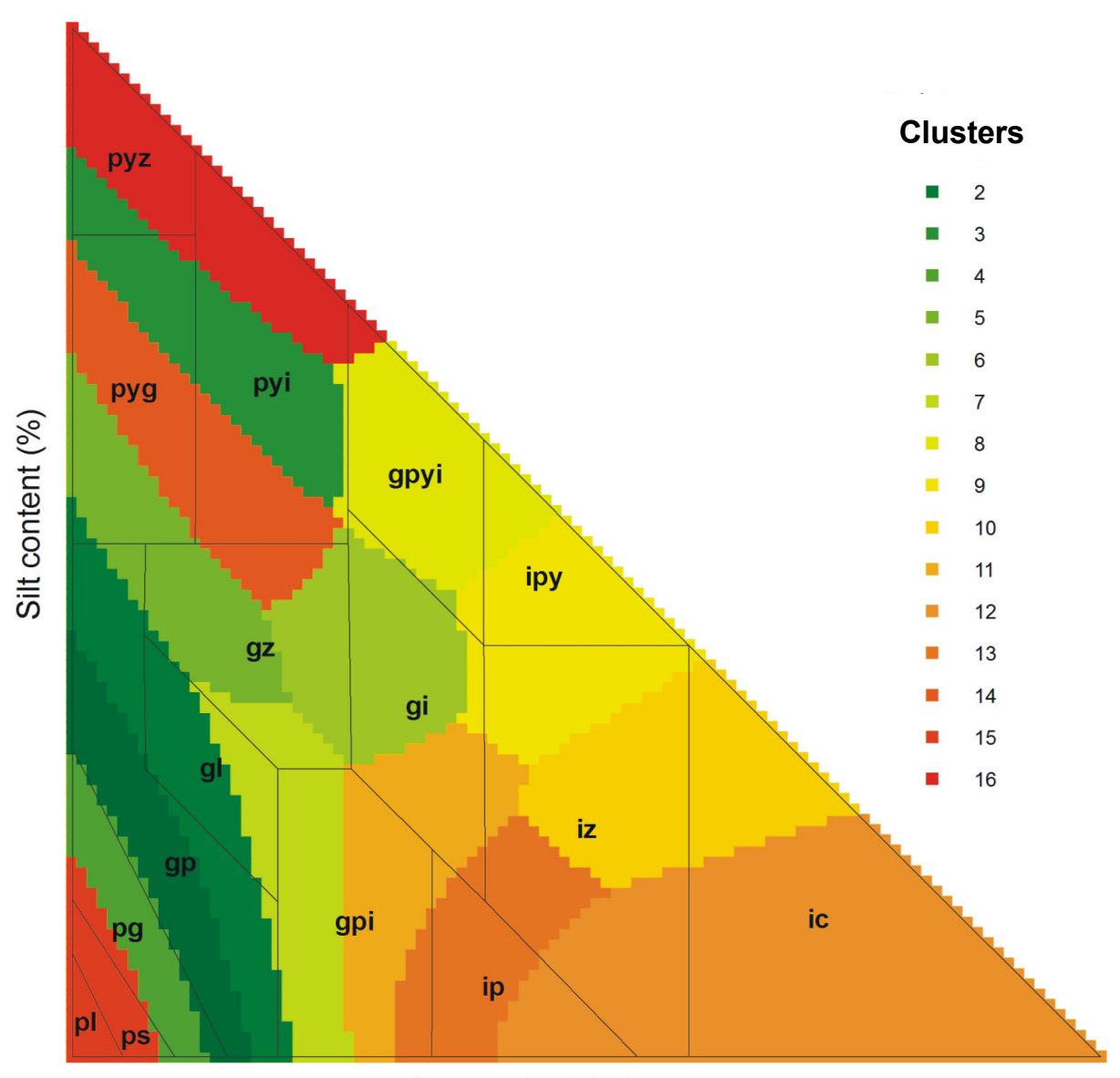

Clay content (\%) 


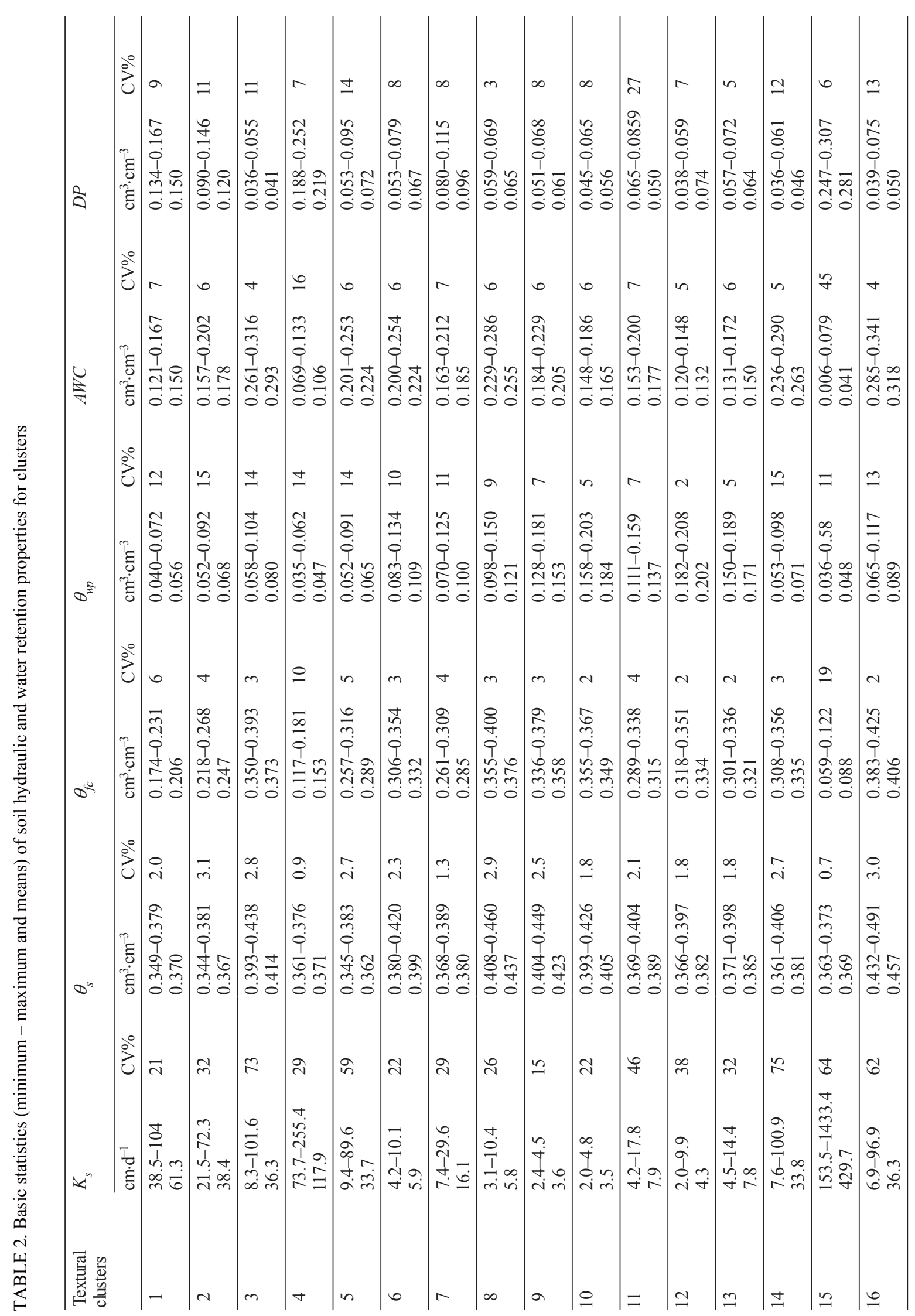


$17 \%$ for $p y z$ to $27 \%$ for $p y g$ ) were obtained, which indicates that approximation of DP on the basis of texture in these soils may be burdened with large error.

The results of $k$-means algorithm application to the dataset describing soil hydraulic and water retention properties $\left(K_{s}, \theta_{s}, \theta_{f c}, \theta_{w p}\right)$ of the 5151 soil texture triangle realizations are shown in Figure 2. A comparison of the shape and size of the Polish textural classes PTG 2008 (Polskie Towarzystwo Gleboznawcze 2009) to the clusters obtained by the $k$-means clustering algorithm shows that besides the coarser texture soils $(p l, p s, p g$ ) also partly gi, gpyi and ipy soils, none of the textural class is entirely coincident with the clusters distinguished on the basis of the soil hydraulic and water retention properties. The remaining textural classes of the Polish classification PTG 2008 (Polskie Towarzystwo Gleboznawcze 2009) include some clusters obtained by the $k$-means clustering algorithm. It is particularly visible for the textural classes of high clay contents, probably because such soils are relatively rare in the real world (Borman 2010). Also pyg, pyi, $p y z, g z$ and $g p$ soils differ from the clusters based on the soil hydraulic and water retention properties, which is in agreement with the results obtained by Borman (2010) and Twarakavi et al. (2010).

Table 2 presents the basic statistics of soil water retention parameters and saturated hydraulic conductivity for 16 clusters obtained by the $k$-means clustering algorithm. For $K_{s}$ the highest value of the $\mathrm{CV}$ was obtained in the fourteenth cluster, which was $75 \%$, while in the textural classes based on PTG 2008 (Polskie Towarzystwo Gleboznawcze 2009) 50\% for $g z$ (Table 1). Groenendyk et al. (2015) have also noted that many clusters based on the $K_{s}$ classification have larger within-cluster variations than the textural classes of the USDA (Soil Survey Division Staff 1993) classification. As to $\theta_{s}$ the highest values of $\mathrm{CV}$ were obtained for the second cluster (3\%) and the textural classes pyi, pyg and pyz (from 4.5 to $6.3 \%$ ). Due to the lack of normal data distribution, the median values of CV for textural classes and clusters were calculated (Table 3). The median value of $K_{s}$ for texture classes was $30 \%$, while it was $32 \%$ for clusters. This means that saturated hydraulic conductivity is better classified into homogeneous groups by the Polish texture triangle than the clusters obtained by the $k$-means cluster analysis. For $\theta_{s}, \theta_{f c}, A W C$ and $D P$, the highest median values of $C V$ were obtained for the textural classes based on PTG 2008 (Polskie Towarzystwo Gleboznawcze 2009) than in the groups obtained by the $k$-means clustering algorithm. This indicates that the soil water retention parameters are better classified into homogeneous groups by the $k$-means cluster
TABLE 3. The CV median values of soil hydraulic and water retention properties for Polish textural classes and clusters

\begin{tabular}{lllllll}
\hline Section & $K_{s}$ & $\theta_{s}$ & $\theta_{f c}$ & $\theta_{u p}$ & $A W C$ & $D P$ \\
\cline { 2 - 7 } & $\%$ & & & & & \\
\hline Textural classes & 29.5 & 2.4 & 5.0 & 11.5 & 9.0 & 10.5 \\
\hline Clusters & 32.0 & 2.2 & 3.0 & 11.0 & 6.0 & 8.5 \\
\hline
\end{tabular}

analysis than the textural classes based on PTG 2008 (Polskie Towarzystwo Gleboznawcze 2009). According to Borman $(2007,2010)$ and Groenendyk et al. (2015), the texture classifications currently used in the World are designed on the basis of similarity with respect to grain size distribution. Soil texture classification could also be performed on the basis of their hydrological properties, including the soil water balance.

\section{CONCLUSIONS}

1. The highest uncertainty in estimation of saturated water content based on the texture has been found for pyi, pyg and pyz. These soils are characterized by high variations of saturated water content within the class.

2. Estimations of the field capacity and permanent wilting point on the basis of textural classes are encumbered with highest errors for the $g p, p g, p l$ and pyg soils, which are characterized by the highest values of coefficient of variation.

3. The soil saturated hydraulic conductivity is better classified into homogeneous classes by the Polish texture triangle than by the clusters obtained by the $k$-means cluster analysis based on the soil hydraulic and retention properties.

4. The soil water retention parameters are better classified into homogeneous groups by the $k$-means cluster analysis than by the traditional textural classes. The cluster analysis using the $k$-means can be helpful for grouping similar soils from the point of view of their retention properties.

\section{REFERENCES}

Abdalbaki A.M. 2016. Evaluation of pedotransfer functions for predicting soil bulk density for U.S. soils. ain shams engineering Fournal (in press). http://dx.doi.org/10.1016/j.asej. 2016.12.002

Ad-Hoc-AG Boden, 2005: Bodenkundliche Kartieranleitung 5. Aufl., 438 p., Hannover, Schweizerbart.

Al Majou H., Bruand A., Duval O., Le Bas C., Vautier A., 2008. Prediction of soil water retention properties after stratification by combining texture, bulk density and the type of horizon, Soil Use and Management 24: 383-391.

Bormann H., 2007. Analysis of the suitability of the German soil texture classification for the regional scale application of physical based hydrological model. Advances in Geosciences 11: 7-13. 
Bormann H., 2008. Sensitivity of a regionally applied soil vegetation atmosphere scheme to input data resolution and data classification. Journal of Hydrology 351: 154-169.

Bormann H., 2010. Towards a hydrologically motivated soil texture classification, Geoderma 157: 142-153.

Boucneau G., Meirvenne M.V., Hofman G., 1998. Comparing pedotransfer functions to estimate soil bulk density in northern Belgium. Pedologic Themata 5: 67-70.

Bouma J., 1989.Using soil survey data for quantitative land evaluation. Advances in Soil Science 9: 177-213.

Bruand A., Pérez Fernandez P., Duval O., 2003. Use of class pedotransfer functions based on texture and bulk density of clods to generate water retention curves. Soil Use and Management 19: 232-242.

Dane J.H., Topp G.C., 2002. Methods of soil analysis. Part 4, physical methods. Soil Science Society of America Book Series, Soil Science Society of America, Madison, Wisconsin.

Groenendyk D.G., Ferré T.P., Thorp K.R., Rice A.K., 2015. Hydrologic-process-based soil texture classifications for improved visualization of landscape function. Plos One 10(6): e0131299.

Hollis J.M., Hannam J., Bellamy P.H., 2012. Empirically derived pedotransfer functions for predicting bulk density in European soils. European Journal of Soil Science 63: 96-109.

Leonaviciute N., 2000. Predicting soil bulk and particle densities by pedotransfer functions from existing soil data in Lithuania. Geografijos Metrastis 33: 317-330.

Manrique L.A., Jones C.A., 1991. Bulk density of soils in relation to soil physical and chemical properties. Soil Sci. Soc. Am. J. 55: 476-481.

McBratney A.B., Minasny B., Cattle S.R., Vervoort R.W., 2002. From pedotransfer functions to soil inference systems. Geoderma 109: 41-73.

Pachepsky Y.A., Rawls W.J., 2004. Development of Pedotransfer Functions in Soil Hydrology. Elsevier, Amsterdam, The Netherlands.
Polskie Towarzystwo Gleboznawcze, 2009. Particle size distribution and textural classes of soils and mineral materials classification of Polish Society of Soil Science 2008. Roczniki Gleboznawcze - Soil Science Annual 60(2): 5-16.

Ramos T.B., Gonçalves M.C., Brito D., Martins J.C., Pereira L.S., 2013. Development of class pedotransfer functions for integrating water retention properties into Portuguese soil maps. Soil Research 51: 262-277.

Saxton K.E., Rawls W.J., Romberger J.S., Papendick R.I., 1986. Estimating generalized soil water characteristics from texture. Soil Science Society of America Journal 50: 1031-1036.

Schaap M.G., Leij F.J., 1998. Database-related accuracy and uncertainty of pedotransfer functions. Soil Science 163: 765-779.

Schaap M.G., Leij F.J., van Genuchten M.Th, 2001. ROSETTA: a computer program for estimating soil hydraulic parameters with hierarchical pedotransfer functions. Journal of Hydrology 251: 163-176.

Soil Survey Division Staff, 1993. Soil survey manual. Soil conservation service. [In:] U.S. Department of Agriculture handbook 18.

Twarakavi N.K.C., Šimůnek J., Schaap M.G., 2010. Can texturebased classification optimally classify soils with respect to soil hydraulics? Water Resources Research 46: W01501.

Terelak H., Motowicka-Terelak T., Wróblewska E., Gawrysiak L., Pietruch C., 2001. Zawartość substancji organicznej w glebach użytków rolnych - mapa. IUNG Puławy.

van Genuchten M.,Th. 1980. A closed-form equation for predicting the hydraulic conductivity of unsaturated soils. Soil Science Society of America Journal 44: 892-898.

Vereecken H., Maes J., Feyen J., Darius P., 1989. Estimating the soil moisture retention characteristics from texture, bulk density, and carbon content. Soil Science 148: 389-403.

Wösten J.H.M., Finke P.A., Janse M.J.W., 1995. Comparison of class and continuous pedotransfer functions to generate soil hydraulic characteristics, Geoderma 66: 227-237.

Received: July 18, 2017

Accepted: January 11, 2018

Associated editor: t. Uzarowicz

\section{Analiza przydatności Polskiej klasyfikacji uziarnienia gleb PTG 2008 dla potrzeb oceny zdolności retencyjnych i właściwości hydraulicznych}

Streszczenie: Celem niniejszego opracowania było zanalizowanie, w jakim stopniu polska klasyfikacja uziarnienia gleb PTG 2008 jest przydatna do określenia zdolności retencyjnych i właściwości hydraulicznych, a ponadto do określenia, które grupy i podgrupy granulometryczne charakteryzują się największym zróżnicowaniem wartości właściwości retencyjnych i hydraulicznych gleb. Diagram uziarnienia został podzielony na siatkę o interwale 1\% poszczególnych frakcji części ziemistych, co pozwoliło na otrzymanie 5151 różnych punktów danych. Przy zastosowaniu programu ROSETTA dla każdego punktu uzyskano parametry zdolności retencyjnych i przewodnictwa hydraulicznego nasyconego gleb. Największe wartości współczynnika zmienności przy szacowaniu pełnej pojemności wodnej na podstawie grup granulometrycznych otrzymano dla pyłów. Gleby o takim uziarnieniu charakteryzują się dużym zróżnicowaniem wartości pełnej pojemności wodnej. Oszacowanie polowej pojemności wodnej i wilgotności trwałego więdnięcia, w oparciu o grupy granulometryczne są obarczone największymi błędami w grupach granulomentrycznych $g p$, $p g, p l$ and $p y g$, które charakteryzują się najwyższymi wartości współczynnika zmienności. Przewodność hydrauliczna gleb jest lepiej klasyfikowana w jednorodne grupy i podgrupy granulometryczne polskiej klasyfikacji uziarnienia gleb PTG 2008 niż klastry uzyskane metodą $k$-średnich w analizie skupień. Zróżnicowanie wartości parametrów charakteryzujących zdolności retencyjne gleb jest lepiej klasyfikowane w jednorodne klastry, otrzymane za pomocą analizy skupień metodą $k$-średnich niż tradycyjne podgrupy granulometryczne. Analiza skupień metodą $k$-średnich może być przydatna do grupowania podobnych gleb pod względem ich zdolności retencyjnych.

Słowa kluczowe: grupy granulometryczne, właściwości hydrauliczne gleb, analiza skupień 